\title{
Productivity Improvement with Rain Water Harvesting and Rechargeable Capacity Study of Stored Runoff Water Collected from Catchment Areas of Litchi Based Production System
}

\author{
R. K. Patel ${ }^{1 *}$, Kuldeep Srivastava ${ }^{2}$, S. D. Pandey ${ }^{3}$, Amrendra Kumar ${ }^{3}$, \\ Akram Ahmed ${ }^{4}$ and Vishal Nath ${ }^{3}$ \\ ${ }^{1}$ ICAR-IGFRI, Jhansi-284003, UP, India \\ ${ }^{2}$ ICAR-IIVR, Varanasi, UP, India \\ ${ }^{3}$ ICAR-National Research Centre on Litchi, Muzaffarpur-842 002, Bihar, India \\ ${ }^{4}$ ICAR Research Complex for Eastern Region, Patna, Bihar, India \\ *Corresponding author
}

\section{Keywords}

Water harvesting structure, Rainwater harvesting,

Rechargeable volume, Pond, Deep furrows

\section{Article Info}

\section{Accepted:}

15 June 2021

Available Online:

10 July 2021
The practice of rainwater harvesting in ponds and reusing the stored water for life saving irrigation of crops and also for domestic purpose is prevalent in India since ancient times. Rainwater of the NRCL farm drained out to outside due to lack of suitable water harvesting structures within the farm premises. The present study on productivity improvement through rain water harvesting and rechargeable volume of stored runoff water collected in different rain water harvesting structures of litchi based production system were carried out at research farm of ICAR-National Research Centre on Litchi, Muzaffarpur during 2017-18. Different water harvesting structures like ponds, trenches and deep furrows have been created as per the farm slope of litchi based catchment area adopting suitable land shaping techniques to store the rain water for multiple uses like cultivation of various crops and fish culture. Physico-chemical analysis of the soil from different catchment area revealed that organic carbon content of the farm soil found low to medium; nitrogen and phosphorus content were medium and potassium content was low. Rain water stored in different ponds showed the storage capacity of 1.45 to 2.50 million litre water per pond with cost of harvested water was Rs 68/1000 L during first year of pond construction and considering the 20 year life span of the ponds, the cost of harvesting water would be a negligible amount of Rs $7 / 1000 \mathrm{~L}$. The stored water in different structures was mostly used for fish culture and makhana cultivation besides, life saving irrigation to newly plantation of litchi, banana and papaya. Vegetables grown on pond bunds were also irrigated during lean period. Total area of catchments excluding water harvesting structures area found to be 25.37 ha. The maximum area of 2.622 ha has been recorded under pond based water harvesting structure and only 0.41 ha area was under deep furrows system. Rechargeable capacity of runoff water in water harvesting structures revealed that the stored runoff volume vanishes by the end of December through evaporation and seepage/groundwater recharge processes. Maximum rechargeable volume of runoff water from the water harvesting structures was computed to be $30624.07 \mathrm{~m}^{3}$. 


\section{Introduction}

Water security can be described as protecting the human societies against the negative impacts of water scarcity and excess, as water is precious to human life and development (Jaramillo et al., 2018). In recent decades, climate change has impacted the availability of freshwater and groundwater, which has affected water security (Allan et al., 2013). Climate change tends to change the rainfall frequency and intensity, and this has led to the change of the balance between dry and wet periods. The change of the balance between wet and dry periods has not only caused water shortage issues during the extended dry period, it has also increased the flood risk due to increased rainfall intensity and created problems for various sectors, such as the agriculture, forestry and energy sectors (Zabidi et al., 2020). Now days, rain water management has become one of the most important exigency to fulfil the need of water requirement of mankind as well as for enhancing climate resilience. Sustainable rain water management also creates better ecosystem services that integrate the management, restoration and sustainability of natural infrastructure to ensure availability and sustainable management of water and sanitation for all. The rainwater stored in various water harvesting structures like pond, trenches and deep furrows is also known as a renewable source for multipurpose use such as domestic use, fish culture and need base irrigation purpose.

Despite the successful application of various rain water harvesting systems in different states of the country, water security has become a risk in recent years, as climate change has changed the dry and wet periods considerably, leading to an imbalance in water availability throughout the year, with prolong dry periods and more frequent extreme rainfall. As a result, the mismatch between water demand and rainfall (water availability) has resulted in the high variability of water resources often leads to flash floods and water shortage issues. With rising urbanization and population explosion as well as unpredictable climate change, water security can be achieved by storing of runoff water in pond and deep furrows. The use of rain water harvesting system is capable of saving energy consumption and helps to reduce carbon dioxide emissions.

The nature has been generous in bestowing the state with bounty of water resources in form of rainwater but in the absence of scientific management of this vital resource from rain and consequent surface flow and underground storages, the water resources go waste and create havoc downstream. The efficient utilization and management of available rainwater is the core issue if the cropping intensity and production is to be enhanced. Rainwater harvesting and its recycling through the micro irrigation systems may revolutionize the agriculture by enhancing the production, productivity and quality of produce. Water is a vital component that determines the full potential of the agriculture sector of any country. Optimum development and efficient utilization of our water resources, therefore, assumes great significance. The practice of rainwater harvesting in ponds and reusing the stored water for life saving irrigation of crops and also for domestic purpose is prevalent in India since ancient times. One can find efficient management of water in the region in traditional farming systems like Kattas and Surangams in North Kerala and Karnataka, Zabo system of Nagaland and Bamboo drip irrigation of Meghalaya and Apatani valley in Arunachal Pradesh (Agarwal and Narain, 1997). It is in this background that the rainwater harvesting assumes significance.

Rainwater harvesting besides helping to meet the ever increasing demand for water, helps to 
reduce the runoff which is choking storm drains, avoid flooding of roads, augment the ground water storage and to control decline of water level, reduce groundwater pollution, improve quality of groundwater and reduce soil erosion (Samual and Mathews 2008). Rainwater harvesting and its recycling can increase productivity and diversify agricultural production by growing of remunerative agricultural and horticultural crops and it can also be integrated with composite pisciculture (Das et al., 2014). Restoration of seasonal waterlogged lands is possible through integration of various techniques of land treatment (land shaping). Further the harvesting of excess water through suitable land shaping involves modifying the surface of the farm land for conservation of excess rain (Patel et al., 2020). The litchi farm area is spread about more than 35 ha having the major plantation of litchi with the age of 5 to 12 years and other agricultural crops under different land use system. Every year rainwater of the farm drained out to outside of the farm due to lack of water harvesting structures in the farm. Keeping the above facts in mind different water harvesting structures like ponds, trenches and deep furrows have been created as per the farm slope of litchi based catchment area adopting suitable land shaping techniques to stored the rain water to study the rechargeable capacity of stored runoff water and multiple use of water for cultivation of various crops and fish culture.

\section{Materials and Methods}

The study was conducted at ICAR-National Research Centre on Litchi, Muzaffarpur, Bihar situated at about $26^{\circ} 5^{\prime} 87^{\prime}, \mathrm{N}$ latitude, $85^{\circ} 26^{\prime} 64^{\prime \prime}$ 'E longitude at an elevation of 210 $\mathrm{m}$. The soil of the research farm was clay loam in texture. A physico-chemical study of research farm soil of different catchment area was conducted. The whole catchment area was divided into different blocks and each block was sub divided into three blocks (Upper, Middle \& Lower) as per the slope gradient and block size. Ten samples (20 cm depth) from each sub block were taken and make a composite sample. All together 100 soil samples were made and analysed in laboratory.

The total study area included catchment and water storage structures was about more than 35 hectare. Majority of the area (90\%) covered with litchi plantation with the age of 5 to 12 years old. Rainwater of different catchment area of the farm was suitably collected and stored in ponds, deep furrows and trenches (Fig 1). Accordingly a number of pods of different size and capacity in the farm were dug out as per the flow of rain water in the down side of the catchment. The waterlogged low land area was converted into ponds of about 2.5-3 $\mathrm{m}$ depth through. The soil excavation work was done through soil excavating machine. The dug out soil was used to form high land pond dyke of 10-12 m width during creation of pond. The pond dykes were used for growing of seasonal crops like maize, mustard, faba bean and vegetables (cow pea, cabbage cauliflower, knol-khol, broccoli, pea) as intercropping with litchi+banana and litchi+papaya combinations (Fig. 2).

Similarly, water conservation was done through land shaping into alternate ridges (1.5 $\mathrm{m}$ top width $\times 1.0 \mathrm{~m}$ height $\times 3 \mathrm{~m}$ bottom width \& $1 \mathrm{~m}$ top width $\mathrm{x} 1.0 \mathrm{~m}$ height $\mathrm{x} 2.5 \mathrm{~m}$ bottom width) and deep furrows system. Dug out soil from furrows is used for making ridges. These ridges remain free of water logging during rainy season while rain water was harvested in deep furrows. Litchi cvs. Shahi \& China were planted on ridges at $8.25 \times 4 \mathrm{~m}$ spacing. The furrows were used for growing seasonal crops round the year and fish cultivation (two furrows) for 5-6 months (Fig.3). Excess rain water was also stored in 
trenches of about $2.5 \mathrm{~m}$ depth made along the pond and deep furrow area. The rain water stored in ponds and furrows was used for fish cultivation and supplementary irrigation purposes. Rechargeable volume of runoff water has been computed on the basis of average cumulative evaporation loss from July-December at Muzaffarpur condition is observed $619.7 \mathrm{~mm}$ whereas, pan coefficient is assumed 0.7 for calculating evaporation loss from ponds. Hence, average cumulative loss during July-December was computed to be $433.79 \mathrm{~mm}$. Total surface area of water harvesting structures computed to be 24392.93 $\mathrm{m}^{2}$ and volume of water evaporates from water harvesting structures would to be $10581.40 \mathrm{~m}^{3}$. Maximum rechargeable volume of runoff water from the water harvesting structures was computed after subs crating the total runoff volume of water accumulated in different water harvesting structures with volume of water evaporated from water harvesting structures.

\section{Results and Discussion}

\section{Site selection and soil nutrient status of catchments}

Selection of suitable site for construction of water harvesting structures like ponds, deep furrows and trench was done as per the slope ingredients of different catchment area. The litchi orchard of different age group was the major land use system as catchment area.

Physico-chemical analysis of the soil from different catchment area was done. The data showed the considerable variation among the chemical analysed due to varied soil condition in different blocks. Soil $\mathrm{pH}$ ranged with 7.909.40 and EC 0.08 to $0.48 \mathrm{dsm}^{-1}$.

Farm soil was poor in organic carbon varied from 0.09 to $0.85 \%$ while nitrogen content ranged from 40.21 to $188.24 \mathrm{~kg} / \mathrm{ha}$, phosphorus
10.5 to $17.42 \mathrm{~kg} / \mathrm{ha}$ and potassium varied from 66.0-308.0 kg/ha. In general, based on data, organic carbon content of the farm soil was low to medium; nitrogen and phosphorus content were medium and potassium content was low.

Water harvesting study of some ponds and their economics

Total 16 ponds of various size were constructed in different location of the research farm and water harvesting capacity and economics of eight pond have been work out. Rain water from whole catchment area was accumulated in the ponds during rainy season with the storage capacity (14.74 million litre water) varied from of 1.45 to 2.50 million litre of water. Total expenditure incurred for construction of eight ponds was about Rs 10 lakhs and hence cost of per litre harvested water was Rs 68/1000 L water during first year of pond construction (Table 1). Considering the $75 \%$ capacity harvesting of water and a minimum life of pond 20 years with the maintenance cost of about $5 \%$ every year (Rs 25000/year), total 109 million litre water shall be harvested.

Therefore, considering the 20 year life span of the ponds, the cost of harvesting water would be a negligible amount of Rs 7/1000 L. Rain water accumulation during rainy season in different pond varied from 1.62 to 2.16 million litre and cost of harvested water calculated Rs 55/1000 L during first year of pond construction (Patel et al., 2020).

\section{Multiple use of harvested water}

The stored water in different structures was mostly used for fish culture and makhana cultivation besides, life saving irrigation to newly plantation of litchi, banana and papaya. Vegetables grown on pond bunds were also irrigated during lean period. 
Table.1 Water harvesting capacity of different ponds and their economics

\begin{tabular}{|c|c|c|c|c|}
\hline S.No. & $\begin{array}{c}\text { Pond volume } \\
\left(\mathbf{m}^{\mathbf{3}}\right)\end{array}$ & $\begin{array}{c}\text { Construction } \\
\text { cost (Rs in } \\
\text { lakh) }\end{array}$ & $\begin{array}{c}\text { Water (million } \\
\text { litre) }\end{array}$ & $\begin{array}{c}\text { Harvested water } \\
\text { cost (Rs/1000 L) }\end{array}$ \\
\hline $\mathbf{1 .}$ & 1620 & 1.00 & 1.62 & 62 \\
\hline $\mathbf{2 .}$ & 2160 & 1.75 & 2.16 & 81 \\
\hline $\mathbf{3 .}$ & 1890 & 1.25 & 1.89 & 66 \\
\hline $\mathbf{4 .}$ & 1620 & 1.00 & 1.62 & 62 \\
\hline $\mathbf{5 .}$ & 2500 & 1.80 & 2.50 & 88 \\
\hline $\mathbf{6 .}$ & 2000 & 1.75 & 2.00 & 50 \\
\hline $\mathbf{7 .}$ & 1500 & 0.75 & 1.50 & 48 \\
\hline $\mathbf{8 .}$ & 1450 & 0.70 & 1.45 & 68 \\
\hline Total & 14740 & 10.0 & 14.74 & \\
\hline
\end{tabular}

Table.2 Area under various catchment and water harvesting structures

\begin{tabular}{|c|c|c|c|c|c|}
\hline \multirow[t]{2}{*}{ Catchment No } & \multirow{2}{*}{$\begin{array}{l}\text { Total area } \\
\text { of the } \\
\text { catchment } \\
\text { (ha) }\end{array}$} & \multicolumn{2}{|c|}{$\begin{array}{c}\text { Area of water harvesting } \\
\text { structures (ha) }\end{array}$} & \multirow{2}{*}{$\begin{array}{c}\text { Area of } \\
\text { catchments } \\
\text { without the } \\
\text { water } \\
\text { harvesting } \\
\text { structures } \\
\text { (ha) }\end{array}$} & \multirow{2}{*}{$\begin{array}{c}\text { Area of } \\
\text { catchment } \\
\text { under water } \\
\text { harvesting } \\
\text { structures } \\
(\%)\end{array}$} \\
\hline & & Pond & $\begin{array}{c}\text { Deep } \\
\text { furrows/Raised } \\
\text { bed }\end{array}$ & & \\
\hline Catchment 1 & 6.77 & 1.13 & - & 5.64 & 16.69 \\
\hline Catchment 2 & 5.57 & 0.62 & 0.41 & 4.55 & 18.49 \\
\hline Catchment 3 & 8.90 & 0.60 & - & 8.30 & 6.74 \\
\hline Catchment 4 & 3.03 & 0.21 & - & 2.82 & 6.93 \\
\hline Catchment 5* & 10.07 & - & - & - & - \\
\hline Catchment 6 & 4.12 & 0.062 & - & 4.06 & 1.50 \\
\hline Total & 38.46 & 2.622 & 0.41 & 25.37 & 10.68 \\
\hline
\end{tabular}

* Runoff of this catchment area going outside the NRCL farm and accumulated in swamp area 
Table.3 Maximum runoff volume stored in different water harvesting structures of various catchments

\begin{tabular}{|c|c|c|}
\hline Catchment No. & $\begin{array}{c}\text { Water harvesting } \\
\text { structures }\end{array}$ & Runoff volume $\left(\mathrm{m}^{3}\right)$ \\
\hline \multirow[t]{7}{*}{ Catchment 1} & Pond 1 & 1949.36 \\
\hline & Pond 2 & 1554.38 \\
\hline & Pond 3 & 1371.3 \\
\hline & Pond 4 & 2830.55 \\
\hline & Pond 5 & 2725.4 \\
\hline & Pond 6 & 5156.19 \\
\hline & Total & 15587.18 \\
\hline \multirow[t]{4}{*}{ Catchment 2} & Pond 1 & 4072.87 \\
\hline & Pond 2 & 3149.45 \\
\hline & Deep furrows/Raised bed & 1521.65 \\
\hline & Total & 8743.97 \\
\hline \multirow[t]{6}{*}{ Catchment 3} & Pond 1 & 1987.05 \\
\hline & Pond 2 & 1580.71 \\
\hline & Pond 3 & 1870.88 \\
\hline & Pond 4 & 1415.68 \\
\hline & Pond 5 & 758.43 \\
\hline & Total & 7612.75 \\
\hline Catchment 4 & Pond 1 & 3500.9 \\
\hline \multirow[t]{3}{*}{ Catchment 6} & Pond 1 & 886.35 \\
\hline & Trench & 4874.32 \\
\hline & Total & 5760.67 \\
\hline
\end{tabular}

Fig.1 View of NRCL farm depicting litchi plantation and location of rain water harvesting structures

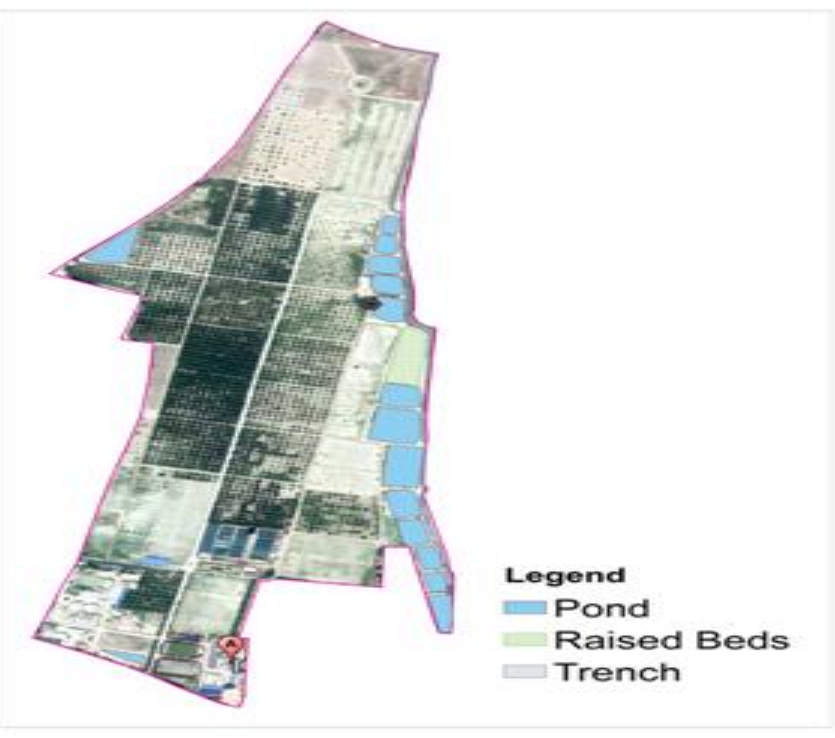


Fig.2 Cultivation of seasonal crops on pond dyke with litchi+banana and litchi+papaya combinations

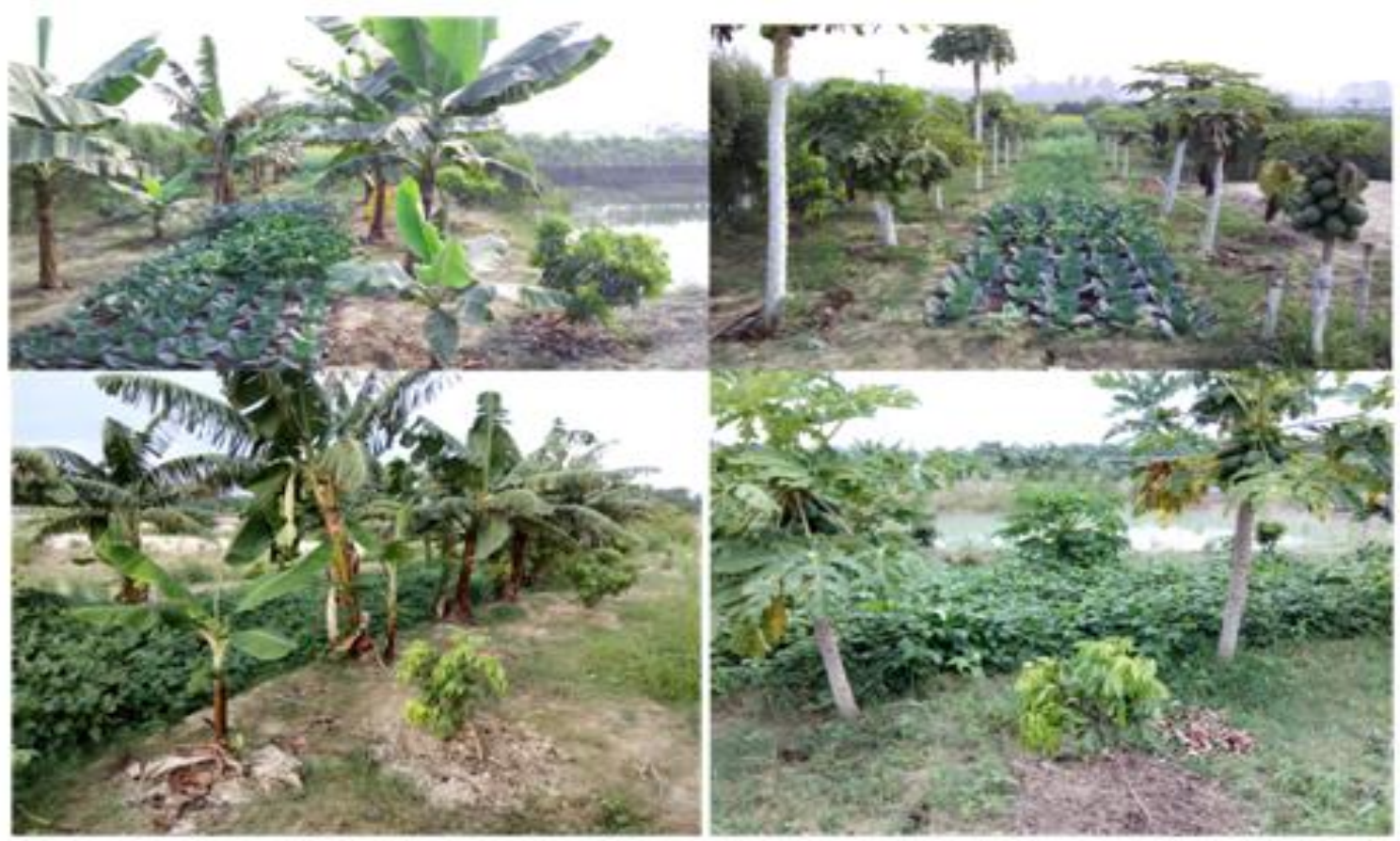

Fig.3 Rain water harvesting in deep furrows and litchi + papaya and banana grown on ridges

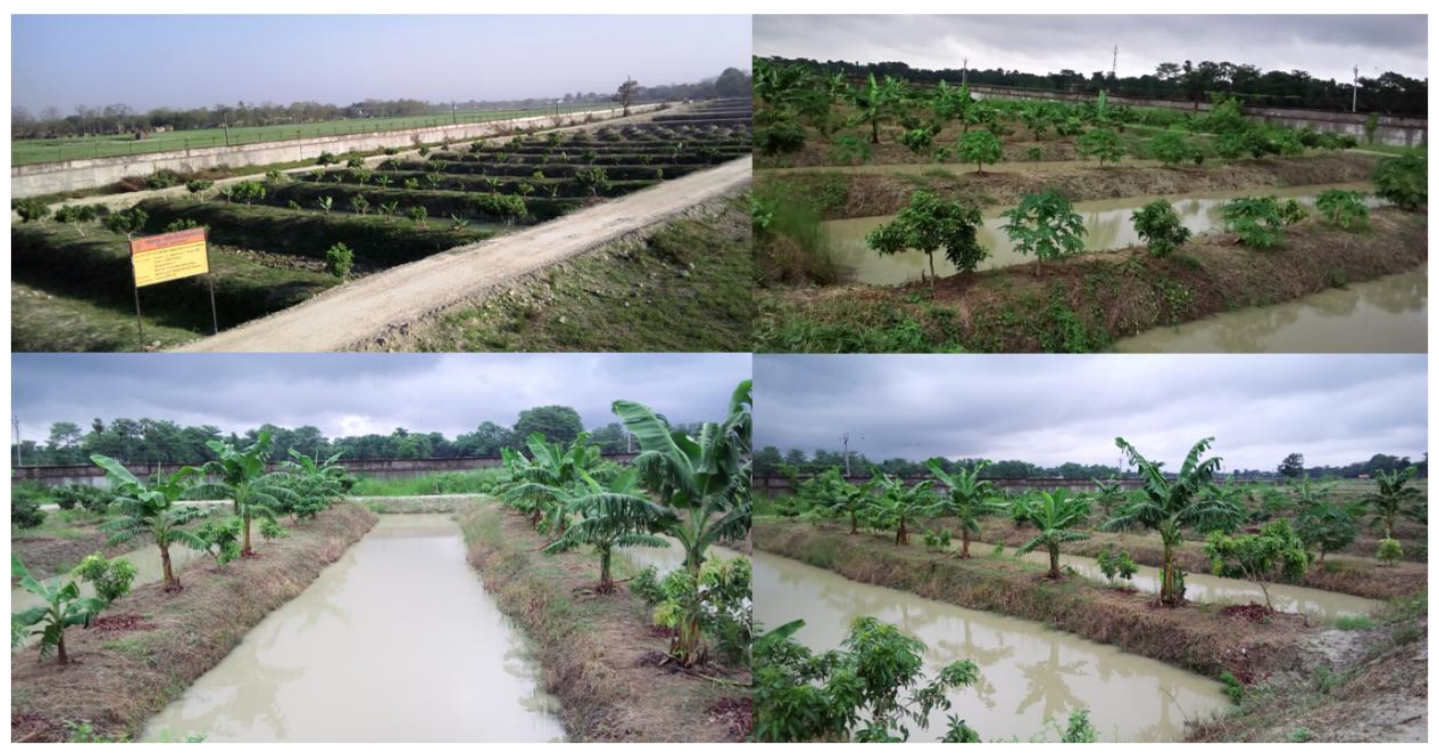


Fig.4 A. Makhana cultivation B. Fish culture in pond stored water

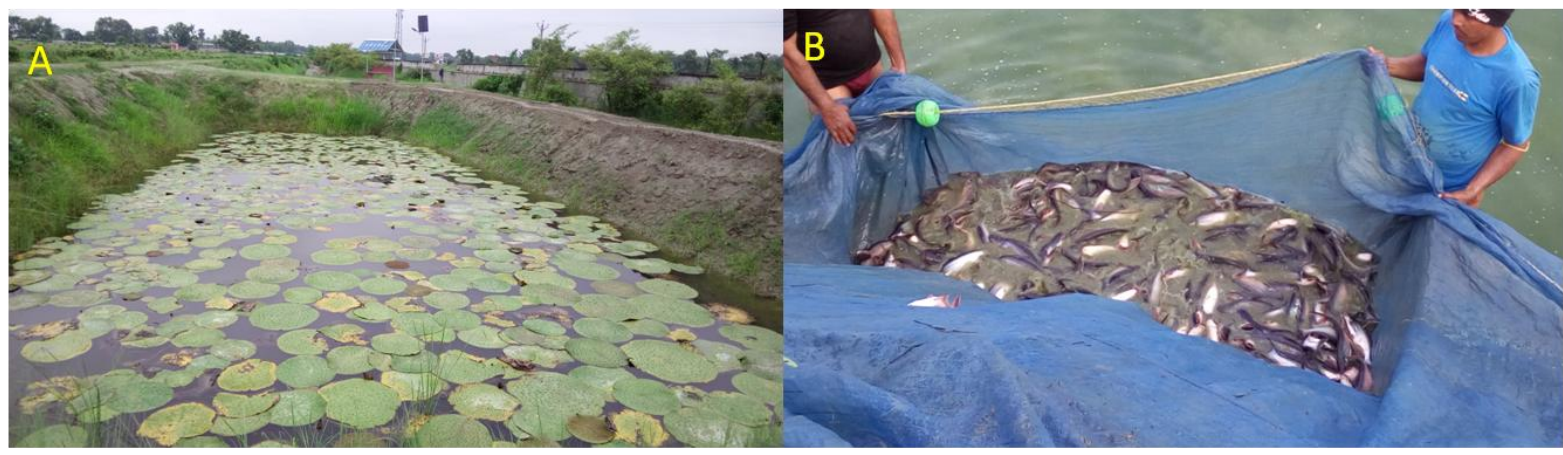

Fig.5 Location of catchment areas and contributing runoff to different water harvesting structures

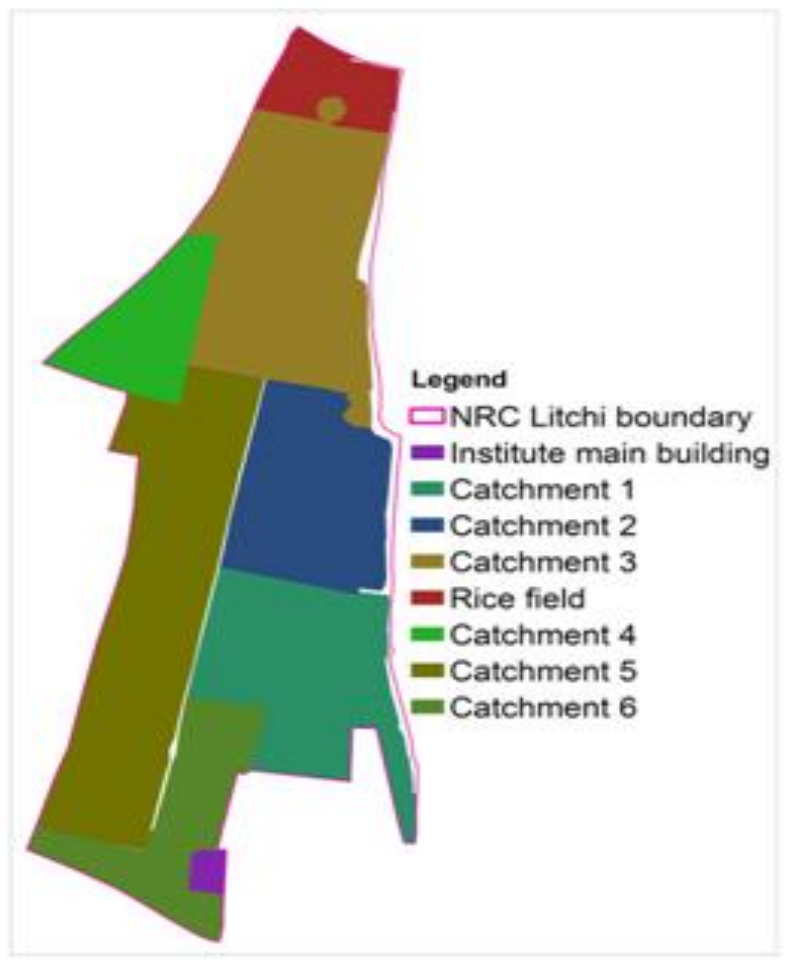


Fig.6 Catchment areas and rain water harvesting structures

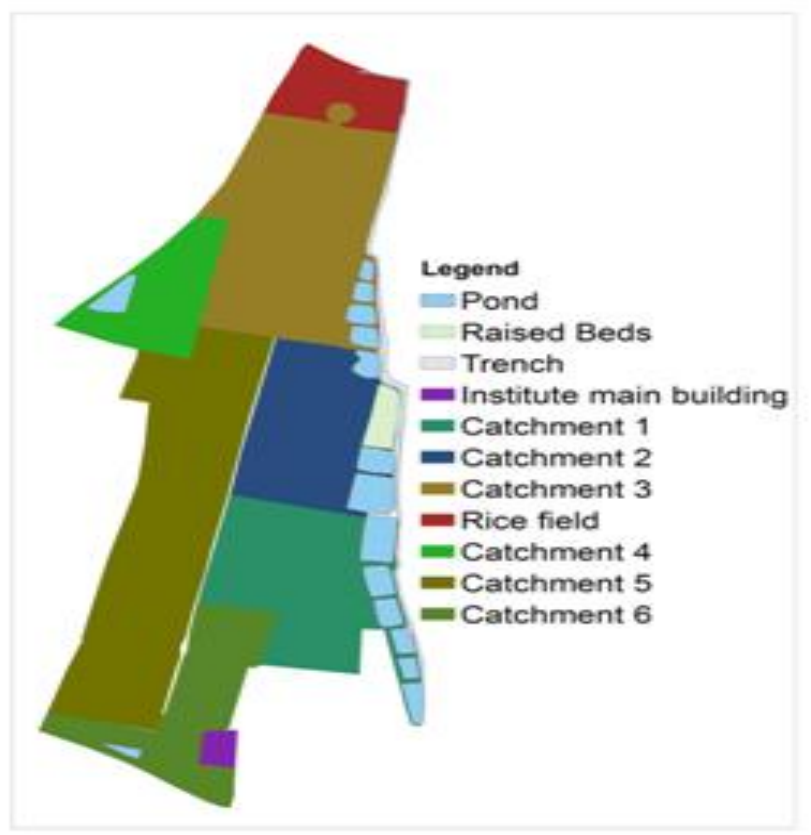

Fig.7 Percentage area contribution of catchment under different water harvesting structures

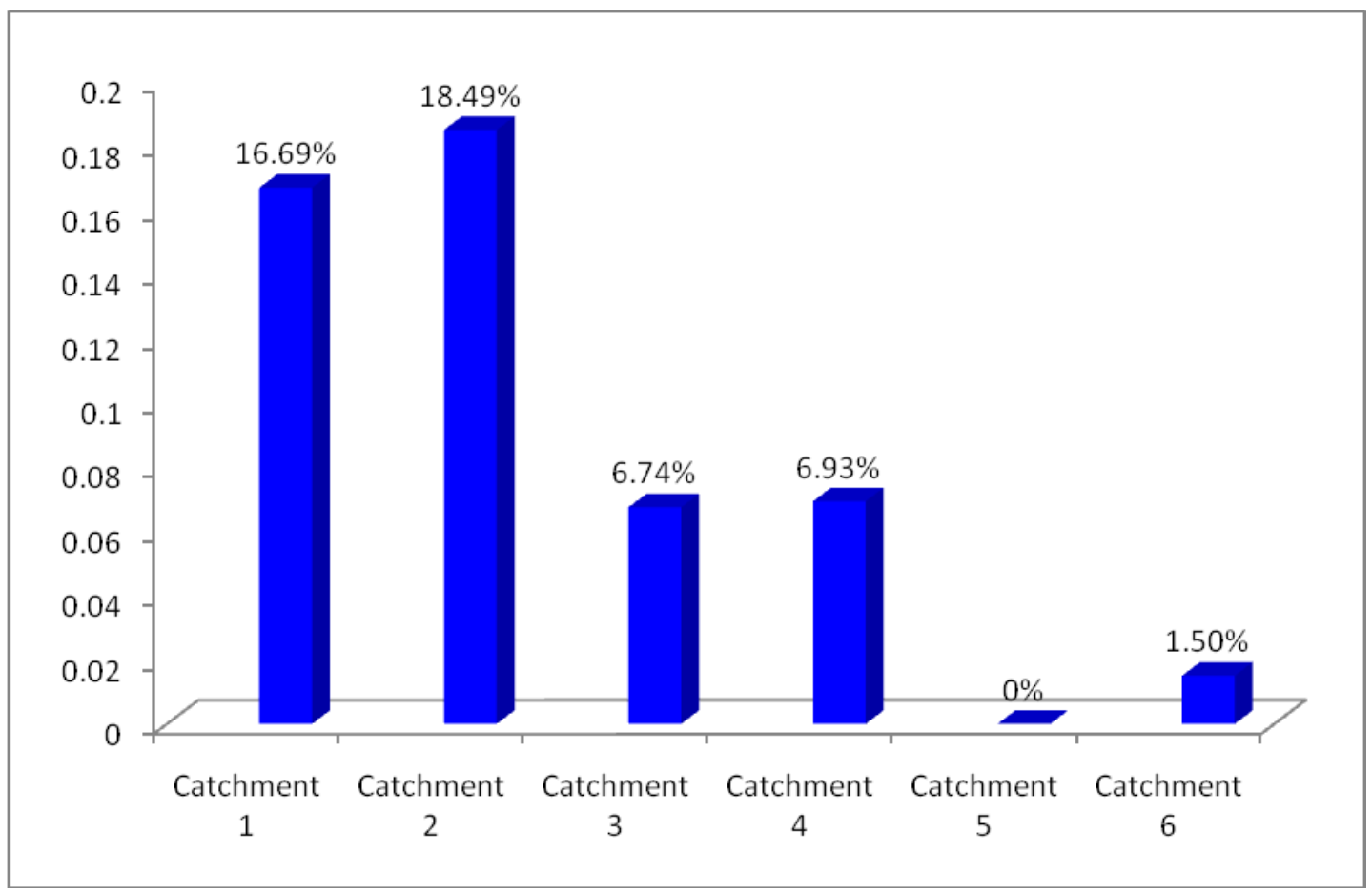


Fig.8 Runoff volume of harvested water in different catchments

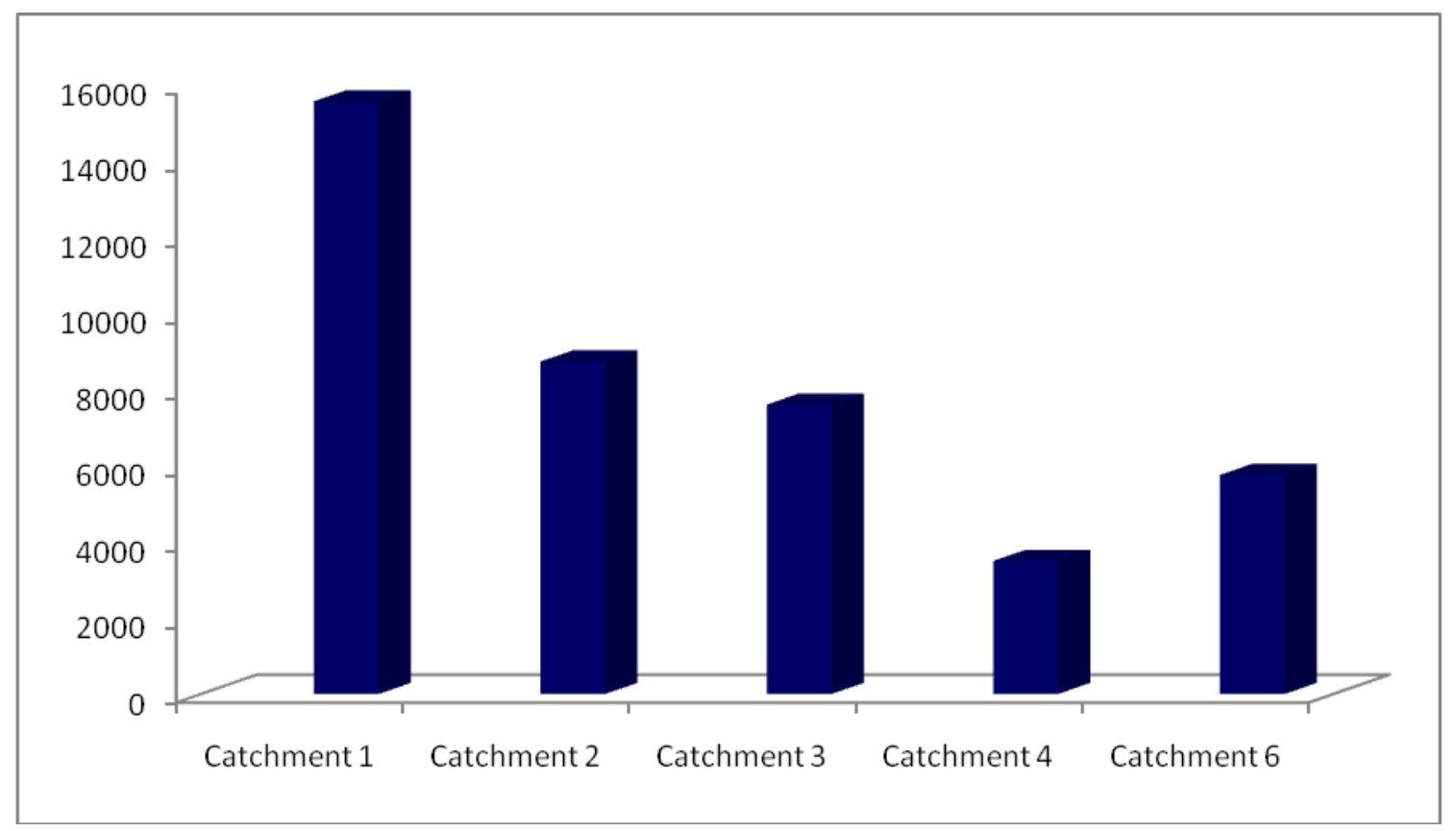

Fingerlings of Pangasius fish (locally known as Jasar) in five ponds and Indian carp in three ponds maintaining 8000/ha stocking density of 25-30 g were released during June and harvested in the month of March.

The fingerlings of Indian carp (catla, rohu, mrigal) have been released during November, 2018 in deep furrows of ridges system with stocking density of 7000 per hectare maintaining furrows water depth of about 1.25-1.5 m. The seed of makhana was shown in pond $\left(120 \mathrm{~m}^{2}\right.$ area) during January 2017 maintaining about 2.5-3 foot water depth throughout the growing period. The harvesting of makhana was done during October month in 2018 and recorded $15.5 \mathrm{~kg}$ yield first time (Fig. 4).

\section{Area contribution under different catchment and water harvesting structures}

Area under various catchment and water harvesting structures is presented in Table 2 and shown in Fig. $5 \& 6$. The total area contributing to runoff collection and storage under different catchment was 38.46 ha, out of which 10.07 ha area under catchment 5, the runoff of this catchment area going outside the NRCL farm and accumulated in swamp area outside of the research farm boundary.

While, the actual total area of catchments without water harvesting structures was 25.37 ha. The highest area of 8.3 ha was recorded under catchment 6 and lowest in catchment 4 (2.82 ha). The maximum area of 2.622 ha has been recorded under pond based water harvesting structure and only 0.41 ha area was under deep furrows system. Pond size ranged from 0.062 to 1.13 ha under catchment 6 and 4 , respectively (Table 2). The highest catchment area contribution (18.49\%) was observed under pond and deep furrows water harvesting structures made in catchment 2 while pond under catchment 6 contributed the least (1.5\%) (Fig.7). However, the total area of catchment under water harvesting structures was $10.68 \%$.The highest area contribution recorded under water harvesting structure made in catchment 2 is due to presence of bigger size ponds and deep furrows. 


\section{Rechargeable capacity of runoff water in water harvesting structures}

Maximum runoff volume stored in different water harvesting structures of various catchments is presented in Table 3 and Fig. 8. The total runoff volume stored in ponds and deep furrows water harvesting structures was $41205.47 \mathrm{~m}^{3}$. The highest runoff volume of water was observed in catchment $1(15587.18$ $\mathrm{m}^{3}$ ) followed by catchment $2\left(8743.97 \mathrm{~m}^{3}\right)$, catchment $3\left(7612.75 \mathrm{~m}^{3}\right)$ and catchment 6 $\left(5760.67 \mathrm{~m}^{3}\right)$ while lowest in catchment 4 $\left(3500.9 \mathrm{~m}^{3}\right)$. Generally, it has been observed that the stored runoff volume vanishes by the end of December through evaporation and seepage/groundwater recharge processes. Therefore, maximum rechargeable volume of runoff water from the water harvesting structures was computed to be $30624.07 \mathrm{~m}^{3}$. The highest runoff volume of water observed in catchment 1 area is due to the presence of more numbers of ponds which accumulated more volume rain water as compared to other structures found in various catchments.

\section{References}

Jaramillo, P. and A. Nazemi (2018). Assessing urban water security under changing climate: Challenges and ways forward. Sustain. Cities Soc. 41: 907-918.

Allan, C., J. Xia and C. Pahl-Wostl. (2013). Climate change and water security: Challenges for adaptive water management. Curr. Opin. Environ. Sustain. 5: 625-632.

Zabidi, H. A., H. W. Goh, C. K. Chang, N. W.
Chan and N. A. Zakaria (2020). A Review of Roof and Pond Rainwater Harvesting Systems for Water Security: The Design, Performance and Way Forward. Water, 12: 3163. https://doi.org/10.3390/w12113163.

Agarwal, A. and S. Narain (1997). Dying wisdom- Rise, Fall and Potential of India's traditional water Harvesting Systems. Centre for Science and Environment, New Delhi.

Samual, M. P. and A. C. Mathew (2008). Rejuvenation of Water Bodies by Adopting Rainwater Harvesting and Ground water Recharging Practices in Catchment Area- A Case Study. In Proceedings of Taal2007: The 12 ${ }^{\text {th }}$ World Lake Conference edited by Sengupta, M. and Dalwani, R. :766776.

Das, A., G. C. Munda, N. S. Azad Thakur, R. K. Yadav, P. K. Ghosh, S. V. Ngachan, K. M. Bujarbaruah, B. Lal, S. K. Das, M. K. Mahapatra, M. Islam and K. K. Dutta (2014). Rainwater harvesting and integrated development of agri-horti-livestock-cumpisciculture in high altitudes for livelihood of Tribal farmers. Indian Journal of Agricultural Sciences 84(5): 643-649.

Patel, R. K., K. Srivastava, S. D. Pandey, A. Kumar, S. K. Purbey and V. Nath (2020). Productivity improvement of low lying area with litchi (Litchi chinensis) based integrated system. Indian Journal of Agricultural Sciences 90(4): 762-766.

\section{How to cite this article:}

Patel, R. K., Kuldeep Srivastava, S. D. Pandey, Amrendra Kumar, Akram Ahmed and Vishal Nath. 2021. Productivity Improvement with Rain Water Harvesting and Rechargeable Capacity Study of Stored Runoff Water Collected from Catchment Areas of Litchi Based Production System. Int.J.Curr.Microbiol.App.Sci. 10(07): 393-404. doi: https://doi.org/10.20546/ijcmas.2021.1007.043 